\title{
STRATEGY FOR STRENGTHENING THE COMPETITIVENESS OF TOURISM DESTINATIONS IN SANUR-BALI
}

\author{
I Made Sudjana ${ }^{1 *}$, I Komang Gde Bendesa ${ }^{2}$ and \\ Anak Agung Suryawan Wiranatha ${ }^{2}$ \\ ${ }^{1}$ Sekolah Tinggi Pariwisata Bali Internasional, Denpasar, Bali, Indonesia \\ ${ }^{2}$ Udayana University, Bali, Indonesia \\ *ketua@stpbi.ac.id,ikgbendesa@yahoo.com, balitruly@yahoo.com
}

\begin{abstract}
Sanur is well-known as morning of the world from Bali, because of the exotic beauty of morning atmosphere on sloping white sand beach. Such beach condition is very suitable for family recreation. Sanur also has so many cultural traditions that are still preserved until today. The problem on this study is how to implement competitive strategy to improve the competitiveness of tourism in Sanur tourism area in Bali. The purpose of this study is to point out the importance of choosing the right competitive strategy and its impact on the change of tourism and consumption in tourist destination, as well as its benefits toward comprehensive economic development. Therefore, in order to be competitive, tourist destination offered to tourists should give superior experience compared to other tourist destinations. In order to attract potential tourists and to make them choose the right choice, the development and implementation of competitive strategy for competitiveness in Sanur-Bali as tourist destination become very important.
\end{abstract}

Keywords - Competitive strategy; competitiveness; Tourist Destination; Sanur

\section{INTRODUCTION}

The development of tourism in Bali has been improving very rapidly and Bali has been known as one of the popular tourist destinations among tourists especially foreign tourists. The combination of the exotic beauty of nature and harmonius lifestyle of its people that based on Balinese traditions and culture has become strong attraction for foreign tourists to visit Bali. Statstics has shown that the number of foreign tourists visiting Bali for the last five years has been increasing, reaching 3,278,598 tourists in 2013 increasing up to 4,927,937 tourists in 2016 [1]. Based on countries, the largest number of foreign tourists visiting Bali in 2016 were from Australia (1,143,157 tourists), followed by China (990,771 tourists), Japan (235,009 tourists), Britain (221,521 tourists), India (187,351 tourists), Malaysia (179.781 tourists), United States of America (170.457 tourists), and other countries [1]. In details, it will be shown in the following Table I: 
Table I. The Best 20 Direct Foreign Tourist Arrivals to Bali in January Desember 2015

\begin{tabular}{|l|c|r|r|c|r|r|r|}
\hline \multicolumn{1}{|c|}{ Nationality } & R & $\mathbf{2 0 1 4}$ & Share (\%) & R & \multicolumn{1}{c|}{$\mathbf{2 0 1 5}$} & $\mathbf{+ / - ( \% )}$ & Share (\%) \\
\hline Australian & I & 991,923 & 26.33 & I & 966,869 & -2.53 & 24.16 \\
\hline Chinese & II & 586,300 & 15.57 & II & 688,469 & 17.43 & 17.20 \\
\hline Japanese & IV & 217,402 & 5.77 & III & 228,185 & 4.96 & 5.70 \\
\hline Malaysian & III & 225,572 & 5.99 & IV & 190,381 & -15.60 & 4.76 \\
\hline British & VIII & 127,040 & 3.37 & V & 167,628 & 31.95 & 4.19 \\
\hline South Korean & VI & 146,088 & 3.88 & VI & 152,866 & 4.64 & 3.82 \\
\hline Singaporean & V & 179,719 & 4.77 & VII & 146,660 & -18.39 & 3.66 \\
\hline American & X & 111,640 & 2.96 & VIII & 133,763 & 19.82 & 3.34 \\
\hline French & VII & 128,350 & 3.41 & IX & 131,451 & 2.42 & 3.28 \\
\hline Taiwanese & IX & 114,504 & 3.04 & X & 124,593 & 8.81 & 3.11 \\
\hline German & XI & 105,471 & 2.80 & XI & 120,348 & 14.11 & 3.01 \\
\hline Indian & XII & 88,074 & 2.34 & XII & 118,678 & 34.75 & 2.97 \\
\hline Dutch & XIII & 76,082 & 2.02 & XIII & 81,678 & 7.36 & 2.04 \\
\hline New Zealand & XV & 62,162 & 1.65 & XIV & 70,415 & 13.28 & 1.76 \\
\hline Russian & XIV & 72,127 & 1.91 & XV & 51,805 & -28.18 & 1.29 \\
\hline Canadian & XVI & 37,523 & 1.00 & XVI & 44,884 & 19.62 & 1.12 \\
\hline Hongkong & XVII & 35,538 & 0.94 & XVII & 36,936 & 3.93 & 0.92 \\
\hline Philipine & XVIII & 32,737 & 0.87 & XVIII & 34,941 & 6.73 & 0.87 \\
\hline Swiss & XXI & 27,281 & 0.72 & XIX & 34,445 & 26.26 & 0.86 \\
\hline Italian & XIX & 30,713 & 0.82 & XX & 33,266 & 8.31 & 0.83 \\
\hline Total & & $\mathbf{3 , 3 9 6 , 2 4 6}$ & 90.17 & & $\mathbf{3 , 5 5 8 , 2 6 1}$ & $\mathbf{4 . 7 7}$ & 88.92 \\
\hline Other Nationalities & & $\mathbf{3 7 0 , 3 9 2}$ & 9.83 & & $\mathbf{4 4 3 , 5 7 4}$ & $\mathbf{1 9 . 7 6}$ & 11.08 \\
\hline Total Arrival & & $\mathbf{3 , 7 6 6 , 6 3 8}$ & 100.00 & & $\mathbf{4 , 0 0 1 , 8 3 5}$ & $\mathbf{6 . 2 4}$ & 100.00 \\
\hline
\end{tabular}

The development of tourism in Bali is not separated from the role of Sanur Tourists Destination, which is one of the favorite tourist destinations in Bali. Sanur is known as morning of the world from Bali, because the beauty of morning atmosphere in white sand beach that stretching sloping as far as $9 \mathrm{~km}$ in the east part of Bali [2]. Such beach condition is suitable for family recreation. Sanur also has so many cultural traditions that are still preserved until today, for examples, historic sites, local geniuses, and various traditional ritual celebrations. The number of tourists visiting the place was as many as 835,099 tourists [3].

Sanur is a tourist destination located on the southern island of Bali, exactly on the eastern part of the city of Denpasar. As a Tourist Destination, Sanur has been growing since the establishment of Bali Beach Hotel by President Soekarno in 1963. Aside from its culture, the main attraction is its beach with beautiful natural scenery and white sand that has attracted foreign tourists from various countries and age.

In Hendrayana in [4], stated that Sanur has an area of $10.57 \mathrm{~km}$ with details as follows; Sanur Kaja with an area of $2.69 \mathrm{~km}$, Sanur village with an area of $4.02 \mathrm{~km}$, and Sanur Kauh with an area of $3.86 \mathrm{~km}$. The geographical location of Sanur Kaja area is that on the East is the Strait of Badung, on the West is Renon village, Kesiman is on its North, and on the South is Sanur. While Sanur village has the following geographical location; on the East is the Strait of Badung, on west side is Sanur Kauh, north side is Sanur Kaja, and on the south is the Badung Strait. Sanur Kauh geograpihical location is as follows: on the eastern side is Sanur village, on the west is Renon village and Sidakarya village, on the north is Sanur Kaja, and on the south is the Badung Strait. Based on these geographical locations, Sanur Village is divided into 9 sub-villages: (1) Singgi sub-village, (2) Panti sub-village, (3) Gulingan sub-village, (4) Taman sub-village, (5) Sindu Kaja sub-village, (6) Sindu Kelod sub-village, (7) Batujimbar sub-village, (8) Semawang sub-village, (9) Pasekute sub-village.

Sanur is also designated as a National Strategic Tourism Area by the government, with its population of 77,742 whose livelihoods are varied from hotel industries, fisheries to 
government sectors [1]. Further, it is expected to bring prosperity to its population using their own areas as tourism products. This can be seen along Matahari Terbit to Mertasari Beach where we can note various arrangements have been made to improve and beautify Sanur as a tourist destination. Of course, the format in governing and improving the tourism products in Sanur is based on the synchronization and agreement between the proposal of the Ministry of Tourism team, the Government of Denpasar, and the proposal from local community. The involvement of various stakeholders on the Sanur improvement is based on the consideration that its existence as a tourist destination will continue to grow without leaving the initial characters of the local community. The plan is this tourist area which is famous for its sunrise will be equipped with gathering places and special places for fishermen who are also the local people of Sanur which should also get attention and chance from tourism [5].

With such potential asset, Sanur should be the favorite of tourism in Bali in particular, and Indonesia in general. Therefore, the government has established Sanur area as National Strategic Tourism Area. To set Sanur as National Strategic Tourism Area is expected to increase the number of visitors as well as maintaining the quality of Sanur as a tourist destination. Law no. 10 of 2009 on Tourism has mandated that tourism is held to improve economic performance, improve prosperity, conservation of nature and strengthen the identity of the Indonesian nation. Tourism is organized with the principle of upholding human rights, cultural diversity and local wisdom, benefiting the welfare of the people, and fairness, equitability, and proportionality between tourists and local people in particular. Choosing the right strategy to manage Sanur will guarantee that in the future.

Based on the background that has been described above, the problem of this study is how the implementation of competitive strategy to improve tourism competitiveness in Sanur-Bali as a Tourist Destination. The purpose of this study is to point out the importance of choosing the right competitive strategy and its impact on the change of tourism and consumption in tourist destination, as well as its benefits toward comprehensive economic development.

This paper is organized as follow: Section 2 presents the literature review. Section 3 describes the proposed research method. Section 4 presents result obtained and following by discussion. Finally, Section 5 concludes this work.

\section{LITERATURE REVIEW}

According to Ritchie \& Crouch in [6] stated that strategic analysis as a key factor in the process that affects the main destination competition is about the effectiveness of developing tourist destination. Tourism could respond strongly enough to change various factors in economics, politics, laws and demography [7]. Regarding the competitiveness of a region, Poon in [8] explained that in order to be competitive, tourist destination must follow 4 main principles namely, considering environmental aspects, making tourism as a major sector, strengthening distribution channels in market and building a dynamic private sector. d'Hartserre in [9] defines competitiveness as "the ability to determine market orientation, maintain market position and share and/or improve market position within specific period of time that has been determined". Kim in [10] defined the competitiveness of tourist destination as "the ability of destinations to give goods and services that performed better than other destinations on aspects of tourism experience that are considered to important for tourists". Enright \& Newton in [11] concluded that competitive destination can attract and satisfy prospective tourists, and this competitiveness is determined by both specific and far-wider tourism factors from factors affecting tourism service providers.

According to Dwyer and Kim in [10], the competitiveness of goals is not the end of policy-making, but intermediate goal in order to reach regional or national economic 
prosperity. In their research, Dwyer and Kim explained that there are four main elements of the competitiveness of destination, namely resources, destination management, condition of demand and situational conditions. Empirical evidence proposed by Cracolici and Nijkamp in [12] shows that the natural resources and culture of a destination are merely the comparative advantage of the tourist area. Indeed, this is a necessary condition but not enough to compete. Therefore, Gomezelj and Mihalic in [13] stated that competitive advantage can only be created by increasing responses to demand challenges, which they claimed that it requires a key role in destination management. Furthermore, explained by Dwyer and Kim in [10] that there are three different sets of business competition environments: 1) the company and organization competition environment, 2) the strategy of the company and organization's goals including the cooperatives and 3) the ability of the company and the organization of destination. Koh and Hatten in [14] and Golembski and Olszewski in [15] argued that public sector should develop the supply of local tourism entrepreneurs by searching opportunities in the market, creating favorable business atmosphere and attracting investors to a certain area. In order to focus on the competitive advantage of the destination, macro business perspective is needed for the entire tourism industry, which means that all stakeholders should work together by focusing on the general benefits of the destination rather than individual interests [16].

\section{PROPOSED METHOD}

This study used literature study approach, which adopted several theories related to competitiveness strategy to support economic development, which has been stated by some experts / researchers, associated with the present-day phenomenon happened in Sanur-Bali as tourist destination area. Variables in this study consist of: 1) Competitiveness strategy which is combination of tourist destinations and 2) infrastructures (policy) that were tried to be reached or achieved by tourist destination based on abilities, strengths and weaknesses in relation to market characteristics and the ability of destination compared to the strengths and weaknesses of competitors.

The location of this study was Sanur-Bali, a tourist destination. The objects of the study were competitive strategy for competitiveness and economic development at SanurBali, a tourist destination. The data were analyzed by two stages, namely: 1) The first stage focused on searching and collecting theories related to destination competitiveness strategy at Sanur- Bali, a tourist destination. 2) The second stage was synthesizing the theories and choosing suitable theories to be used and applied to Sanur- Bali, a tourist destination. Several authors such as Pernecky \& Jamal in [17], Riley \& Love in [18], and Ryan in [19] have encouraged researchers in tourism to use qualitative methodology. Since the purpose of this study is to increase the understanding of individual small businesses as contributors to the competitiveness of destination, qualitative approach was chosen as research methodology. Because of the socially developed tourism space [20], constructivist paradigm is applied, assuming relativistic ontology and subjectivist epistemology [21], recognizing that no interpretive truth is existed but there are many realities.

\section{RESULT AND DISCUSSION}

Based on the analysis, it can be revealed/explained that competitive assessment strategy of tourist destination competitiveness became important instrument in positioning and marketing to analyze strategic tourist destination, because the competitive advantage can increase market share, create loyal customers, increase visit in tourist destination and as a result, it can increase income obtained from tourism. Competitive advantage is the result of the formulation and implementation of strategies for the success of the competitiveness of tourist destination. The competitiveness or competitive 
advantage of a tourist destination is not determined once for forever and absolute, but it is a dynamic category that is constantly changing and can be maintained only for a certain period of time. This is very useful for Sanur-Bali, a tourist destination as reference in understanding competitive position of the weakest and strongest of a destination and to anticipate the level of competition which changes very quickly.

The changes occured are related to competitive advantage and must be based on changes in the legal framework in the area where the tourist destination is located, and changes that occured in the business environment, the desires, preferences and needs of tourists, and members in the target group. To respond adequately to the changes occured in the environment and to maintain a competitive position achieved in relation to other destinations, demand a change in the competitive strategy that must coordinate with the current situation and conditions. Dwyer et al. in [22] tested the competitiveness model of destination of Dwyer and Kim in [10] with stakeholders in the Korean and Australian tourism industries. Their results showed that respondents do not differenciate between destination management activities that are the responsibility of the public sector (e.g. destination image, awareness of international destination), things that become private sector responsibility (e.g. entrepreneurial quality of tourism business, attitude of companies co-operation) as well as collaborating the public sector as part of destination management activities. It does not differenciate between government commitment as a separate factor including government leadership in tourism development and public sector commitment toward tourism training, which refers to the need of an active government role in facilitating the development of destination.

This is in line with some research results conducted by some researchers, like research conducted by Acep Hidayat in his research entitled "Implementation of Tourism Policy in Perspective of General Agreement on Trade in Services (GATS): A Study in Bandung" [23]. This study viewed that tourism development in the past had been too favorable to a small portion of tourism stakeholders, conglomerates, and big investors. In line with the era of reformation and regional autonomy, tourism stakeholders, especially the people around tourist objects and attractions have not felt that the impact of tourism development currently was in their favor. Thus, the problem of this research was that most of the aspirations of tourism stakeholders have not yet materialized while the implementation of trading has begun gradually, which means that the competition of tourism business with the nomenclature Tourism and Travel Related Services become more difficult. The research used descriptive method with qualitative approach. The data were obtained from the informants, beginning with the initial informants, and the data that could not be provided by the initial informants were continuously pursued through the second informant and rolled on and on until the required data was sufficient. The data was gathered through informal and unstructured interviews using interview guidelines as a reference. For data requiring checking, triangulation of data sources from Cibaduyut shoe craftsmen, restaurant entrepreneurs, and tourism officials at the provincial level are conducted. This study highlighted some stakeholders from entrepreneurs, tourism professional associations, and communities around tourist objects and attractions, who are the parties governed as consumers of "tourism policy implementation". The outcome of that will depend on consumer empowerment is a new thing that enriches the theory of public policy in particular and kybernology in general. The result of the study showed that the implementation of tourism policy has not yet been able to formulize the aspirations of tourism stakeholders because some of the affected (the consumers) are not involved in the making of various joint programs, making of regional regulations, and the lack of guidance and unclear tourism development programs. The understanding of GATS, especially Tourism and Travel Related Services (TTRS) is still weak and not same among tourism stakeholders. It can be one obstacle in achieving the goal of tourism development. 
In line with this, Hermana in [24] conducted a research entitled "The Influence of Tourism Strategic Planning as One of Determinant for Public Management of Tourism Development of Banten Province". This dissertation of Postgraduate Program of Padjadjaran University examined the implementation of Indonesian tourism development which is required to be able to adapt itself to the development of the environment, both on the national, regional and international scale relating to political, economic and sociocultural fields, defense and science and technology. Therefore, the success of Indonesian tourism development is determined by three things, namely: success in marketing, success in product development, and success in creating good quality tourism human resources.

This research used survey method with quantitative approach in Banten province with research object were the staffs of Department of Culture and Tourism through path analysis. The result of this research showed $31.7546 \%$ epsilon value, it showed that there were many other factors outside strategic planning that influenced the development of tourism. The results showed that the strategic planning of tourism had a significant influence on the development of tourism in Banten Province, although still not optimal. Similarly, the main expectation factor of internal interest and the main expectation of outside interests had a significant influence on the development of the development of tourism. While the data base and coordination factors provided insignificant influence on the development of tourism, this was defined as a challenge for policy makers to improve in the future. Furthermore, as new findings, they must be realized because it involved various things, such as: human resources mastering the tourism field were still very rare so that the supporting resources became weak; another aspect was the lack of the use of technology. This should be a consideration for policy makers even though demandinghigh cost.

Iyus Wiyadi in [25] also conducted a study entitled: Public Relations Strategy in Forming Perception, Attitudes and Preferences of Foreign Tourits and Their Influence on the Positioning of The National Tourism Industry. The research aimed to know (1) the influence of public relations strategy of national tourism industry to perception, attitude and preferences of foreign tourists to tourism product in Indonesia; (2) the influence of perception, attitude and preference on positioning of national tourism industry; (3) the prospects of the national tourism industry. The data used in this research was based on cross sectional, using structural equation model (SEM) analysis method. The units of analysis are tourists from 11 countries that were tourist generating countries visiting 5 major tourist destinations in Indonesia: North Sumatera, West Sumatera, Yogyakarta, Bali and South Sulawesi. Meanwhile, the observation unit was done to foreign tourists with 210 samples of tourists (United States, Germany, UK, Netherlands, France, Japan, Korea Republic, Australia, Malaysia, Singapore and Taiwan). The results of the study showed: (1) the influence of public relations strategy for each variable on the perception, attitude and preference of national tourism product was significant; (2) partially influence of perception, attitude and preference of tourism product on the positioning of national tourism industry was $50.39 \%, 10.50 \%$, and $9.34 \%$. Meanwhile, simultanous influence of perception, attitude and preference of national tourism product was $70.17 \%$ and $29.83 \%$ influenced by other factor; (3) the prospect of the national tourism industry faced considerable opportunities: the tendency of increasing the number of tourists visiting from 2006 until 2009. This tendency would increase if accompanied by the implementation of communication efforts, especially public relations strategy formulated systematically and integrated. Thus, it was expected to restore the impression or image of foreign tourists to the national tourism industry as provider for tourism products and objects based on attractions or natural attractions, ancestral cultural heritage, events, and also commercial attractions. Related to the study that will be conducted that what has been researched by Iyus Wiryadi has more view only on the aspect of tourism marketing which is one dimension of tourism development that will be the study of reseacher. 
Several studies related to this research with different results and methods have been done, namely research conducted by Yuri Suryahadi in [26] with the title Analysis of Perception and Consumer Preference on Kepulauan Seribu National Park Area using cluster analysis method, Cochran analysis, conjoint analysis, and gap and biplot analysis. The objectives of this study were: (1) to identify the demographic and psychographic characteristics of respondents of Kepulauan Seribu National Park Area (2) to analyze what attributes were considered by the respondents when going on a tour visit to Kepulauan Seribu National Park area (3) to analyze perceptions of Kepulauan Seribu National Park Area respondents (4) to analyze the respondent's preference for Kepulauan Seribu National Park and the position of Kepulauan Seribu National Park in the eyes of respondents compared to similar areas (5) to formulate the appropriate managerial implications for the development of Kepulauan Seribu National Park in terms of marketing strategy. In this study, the research variables used are (1) tangible (2) reliability (3) responsiveness (4) assurance (5) empahty. The results of the test using conjoint analysis with the main attribute of Kepulauan Seribu National Park showed that the most preferred attribute of the respondents was the wealth of natural resources and ecosystem, coastal and beach tourism, and information center.

In addition, Lopes in [27] conducted a research entitled Post Hoc Tourist Segmentation with Conjoint and Cluster Analysis with Conjoint and Cluster Analysis method. The purposes of this study were (1) to find out the preferences of tourists (category of young age) (2) to know the segmentation based on the preferences of tourists. The research variables include: (1) Weather (2) Cultural offer (3) Kind of Destination (4) Leisure Offer $\&$ Night Fun. Based on the results of the test using conjoint analysis, it was known that the most preferred attribute of the respondents was the sunny weather, the high cultural attraction offer, the type of beach destination with the high offer of activities at night, the price with the range of 30 Euros and length of visit about 2 weeks.

Meanwhile, research conducted by Mehmet Mehmetoglu in [28] entitled "Typologising Nature-based Tourists by Activity-theoritical and Practical Implications" showed that many of the existed typologies were theoretical and static (assuming the tourists did not change the route) so there was a need to work more empirically, especially related to a tourist activities based approach. The objectives were: (1) to know the segmentation of nature-based tourists on the basis of travel activities; (2) to find out whether the segment has different motivations for the current trip, as well as to find out the further profiles of each segment according to the socio-demographic characteristics of various trips. This research used cluster and conjoint method, wherein using cluster, there were 3 segmentation based on travel activities. Among them, segment I: orientation to culture and activity pleasure, segment II: orientation to nature activity, and segment III: orientation to activities in natural setting. However, the main differences among them were the tourists with various high activity (active) and those who assessed different activities as low (passive). The conjoint method was used to find consumers references based on grouped tourists, tourism activities belonging to the cluster of active tourists were activities oriented towards culture and nature activities, whereas the only funoriented tourism activity was cluster that classified as passive tourists. As an implication the other theories, the weak role of demographic and travel characteristics in distinguishing between different types of travelers, should also be mentioned. Only two (income and travel mode) of the six demographic and travel features distinguished three cluster-based activities from each other. In other words, and as noted by some studies, developing a theoretical model based only on demographic and travel characteristics were not useful for all contexts. The study also showed that psychographic information was stronger in understanding tourism behavior.

A study conducted by Mohd Salleh Daim, Ahmad Nazrin Aris Anuar, Norajlin Jaini in [29] under the title The Practice of Sustainable Tourism in Ecotourism Sites among Ecotourism Providers explained that ecotourism and sustainable tourism have the same 
goal to link conservation, economic and rural development goals. Ecotourism also offers a new educational experience for tourists, and it should be developed and managed in a such way that is environmentally sensitive while protecting the environment. With the entry of eco-tourism to Malaysia, the number of tourism agencies interested in becoming ecotourism providers was increasing rapidly. Since there were no specific guidelines in ecotourism practice, many tourism agencies usually proclaimed themselves as eco-tour providers and served in the ecotourism industry without any restrictions. This situation would definitely affect the environment due to lack of proper ecotourism practices. Therefore, the aim of this study is to find out the current standard of ecotourism practice among ecotourism providers in Malaysia, and also to determine whether ecotourism providers follow sustainable tourism practices. This research tried to assist in identifying best practices for ecotourism in Malaysia towards sustainable tourism. Amiluhur Soeroso in [30], Green Tourism Development in Kaliurang-Kaliadem, Sleman, Yogyakarta, An Implementation of Conjoint Analysis, examined the preferences of tourists on the potential of green tourism in the Kaliadem region and knew the value of the economic benefits of developing new and efficient tourism resources and plan for its development strategy. With the method of conjoint analysis, we could get information about characteristics of tourists visiting kaliadem based on the preferences of tourists as well as the value of economic benefits and development strategies for that tourist area.

Arida in [31] explained that tourism activities are considered sustainable if they meet the requirements of ecology, social, culture, and economic. First, ecologically sustainable, i.e. the development of tourism does not cause negative effects to the local ecosystem. Secondly, it is socially acceptable based on the ability of the local community so that it won't cause social conflict. Thirdly, culturally acceptable, and can be adapted by local people to different tourist cultures, and. Fourthly, economically benefit and improve the welfare of society.

Sustainable tourism development could not necessarily be manifested easily where many obstacles should be encountered. Page in [32] mentioned four reasons why the manifestation of sustainable tourism development is difficult to implement. First, too many theories and experts and too few resources, and less time to act. Second, there is a huge demand from the tourism sector. Third, while there is growing awareness of the environment but still dominated by the attitude that show-off the pleasure of vacation rather than responsibility for continuity in the tourist area. Fourth, changing the necessary paradigm, toward the social and a more harmonious environment lifestyle. Muller assumed that the implementation of sustainable tourism is a long and difficult way. If we traced deeper to the definition of tourism based on the [33], it was stated that tourism is a temporary, short-term movement from one person to an area where he doesn't work or live there on daily basis and also not an activity which tourists do everyday. Tourism in several dimensions, there are two that differenciat; the definition of time and minimum distance Warpani in [34] defined that tourism is one's travel activity to and reside in other place outside the neighborhood for less than a year continuously, with the intention of having fun. Based on the various definitions of tourism, there are four factors underlying the definition of pure tourism, ie, first, the trip is done for a while, at least 24 hours and less than a year. Second, the trip is done from one place to another, Third, the trip, regardless of its form, must always be linked to sightseeing or recreation, and the fourth, people who do the trip don't not earn a living at the place they visited and solely as consumers in that place [35].

Warpani in [34], viewed tourism as a system and categorized it in terms of demand and supply. The demand component consists of the elements of the person, incited by the desire of the person to travel and the ability to do it, while the components of the stock are tourist attractions, as well as transportation, information and promotion and service. From the eyes of a planner, all elements are important to be paid attention to, both in terms of human resources, natural resources, as well as the built-in resources. The 
element of tourism is essentially a sector of industrial activity that directly or indirectly becomes an integral part of all tourism activities.

In the development of tourism, especially tourism, development of tourism supply is very important to be developed, especially tourist destinations. In this case, tourist destinations are a complex form of tourism products and services. Based on that, a destination is not solely one but consists of components that are mixed generally called destination mix. There are four components that should be considered in tourism offers, known as $4 \mathrm{~A}$, i.e. First, attraction; it is the most important component of the tourism system because it is the motivation of tourists to visit the tourist destination. Second, amenities (supporting facilities); that are facilities such as accommodation, food and beverage, shopping center, sports and entertainment facilities and other facilities. Third access (transportation), how tourists in the mobility to tourism destination or in tourist's destination, not only physical transportation but also related infrastructures, facilities, operationals and government policies on transportation. Fourth, Ancillary Service; it is a service provider for the needs of travelers, including tour guides, advertising agencies, consultants, education and training service providers, and coordinates with local tourism agencies. The need for supporting tools is ensure the smooth transfer process in line with the desired time. Factor that is not less important in planning and developing tourism is related to transportation. The main element of the transportation system consists of passengers / goods to be moved, vehicles / transportation equipment as a means, road as infrastructures of transportation, terminals, and organization as a transport manager to achieve sustainable destination competitiveness. This is also strengthed by the model developed by Pike \& Page in [32]. In his research entitled "Destination Marketing Organizations and Destination Marketing" in Figure 1 as follows:

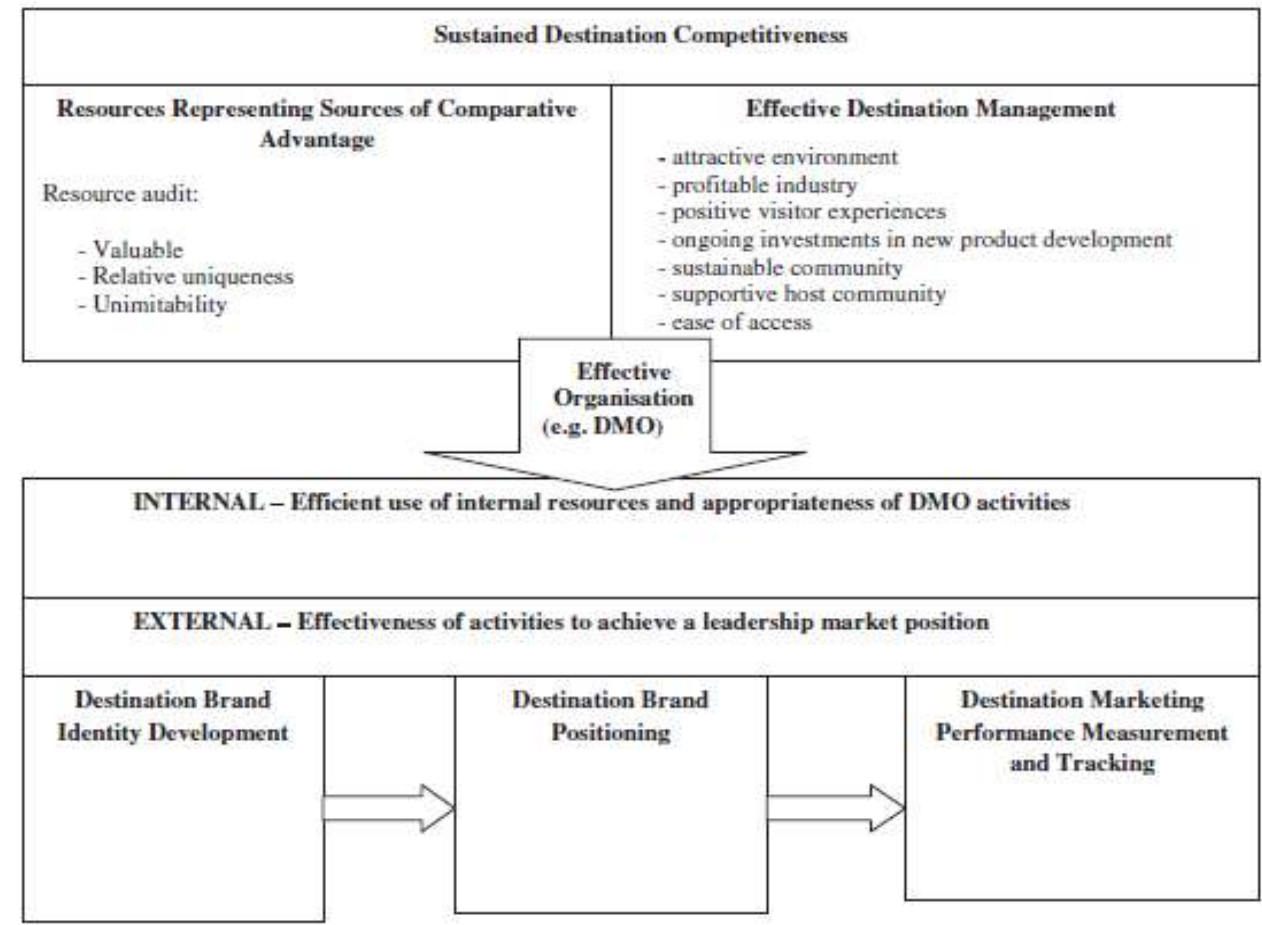

Fig. 1 Destination Marketing Framework

According to Larsen in [36], the tourism experience consists of three parts: the planning process, the actual mission of the trip, and the memories of the trip. Planning a pre-trip is part of the initial stage. The next step is the search for consumer information which is an important part of the travel experience. 
In Sanur tourist destination, there are some sports that become tourism advantage compared to other tourist destinations in Bali as well as in Indonesia, even the world. When tourists come to Sanur beach, tourists will be able to see various marine tourism activities, such as water tourism (banana boat, jet ski, parachute laying, glass bottom boat), diving tours (free dive, scuba dive, sea walker), water sports (surfing, kite surfing, wind surfing, wake boarding, standup paddle, fishing) and cruise tours (sailing with jukung). As Appeared in the following Figure 2:
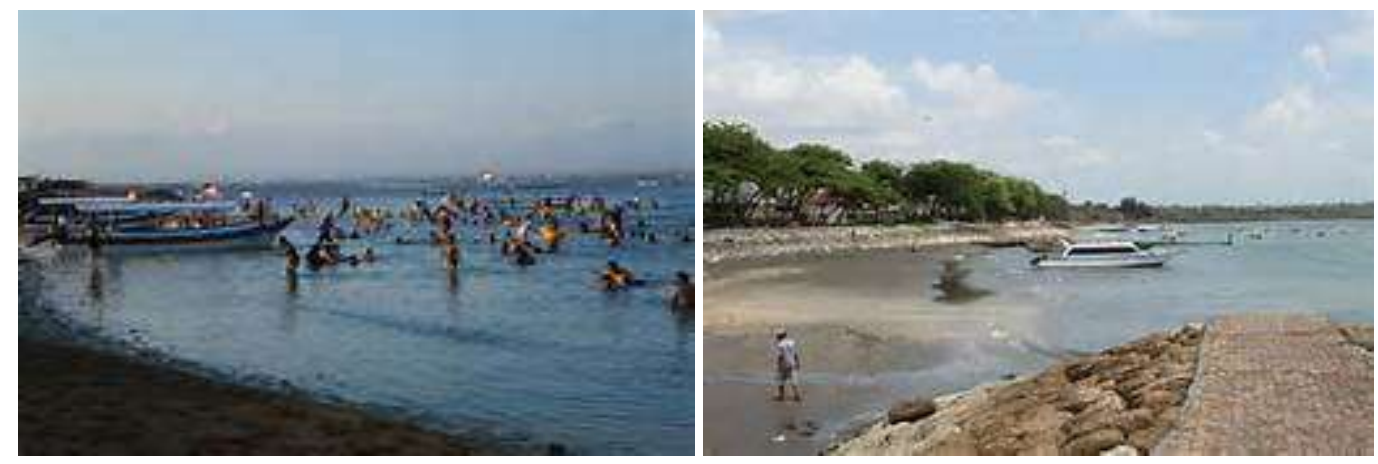

Fig. 2 Various water sport sctivities in Sanur

Sanur is one of the oldest areas in Bali, and the first area who have resort. Sanur began to be visited by tourists since the 1930's. The beginning of coastal development of Sanur happened when it was visited by foreign artists. Among them are the couple who are dancers and photographers from the United States of America, whose names were Katharane and Jack Marson. Other famous visitors are Hans and Rolf Neuhaus brothers from Germany, they both opened an art gallery in Sanur, and the Belgian painter AdrienJean Le Mayeur de Marphes, now some of his works are still stored in Meseum "Lemayeur" located in Sanur Beach, and the museum still stands there to this day.

In 1963, the first President of the Republic of Indonesia, Ir. Soekarno officially opened "Grand Bali Beach Hotel" with the number of rooms at that time were 300 rooms and also still stand tall and firm there until now. The main attractions of sanur are the beauty of white sand and the spectacular view both the landscape and the underwater beauty. The existence of this beach is also very important for the sustainability of social activities such as religion and culture. Besides that, sanur beach is also famous for its sunrise beauty, which can be seen in the following Figure 3:
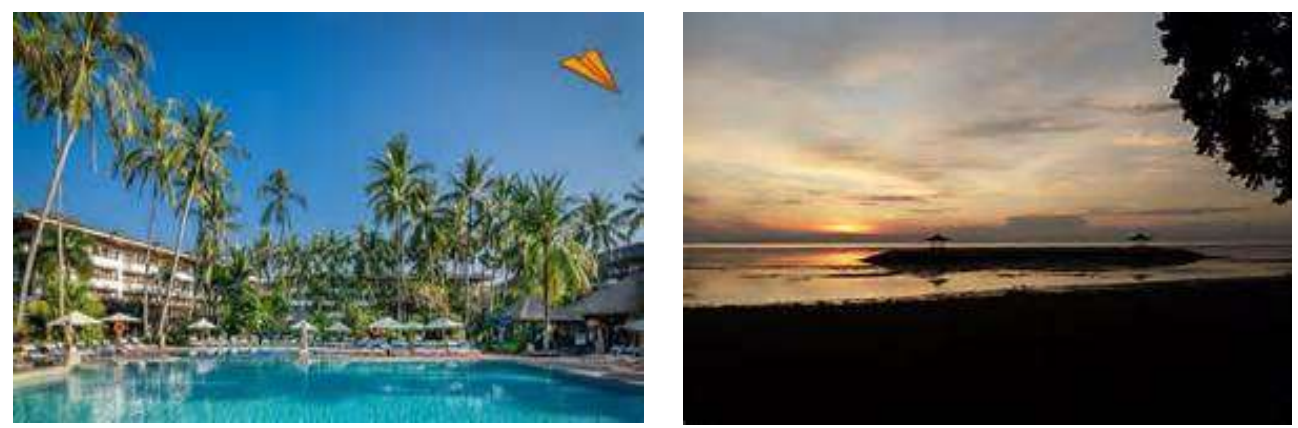

Fig. 3 Hotel Bali Beach and sunrise in Sanur

One of the advantages of Sanur Tourist Destinations is that tourists will be able to plan a tour to Sanur as a tourist destination. The role of Sanur tourist destination information becomes very important. Through prior trip planning, tourists get some important information to develop their travel plans. In this case, the information available to the 
tourists can affect various aspects of decision making, especially its decision to visit [3739]. Thus, social media helps travelers to search, organize, and share their travel memories and experiences through blogs (e.g. Blogger and Twitter), online social networks (e.g. Facebook, RenRen, and Trip Advisor), media sharing sites (e.g. Flickr and YouTube), social bookmarking sites (e.g. Delicious) and other means [40]. Everyday millions of people join blogs and travel sites to share travelers' travel experiences. Therefore, blogging plays an important role in the process of tourism production and consumption. Furthermore, the web-based platform enables real-time recording and sharing of travel experiences [41]. Thus, blogs and travel websites are a form of words communication from mouth to mouth (WOM) that allows travelers to gain insight and view from other travelers [42].

Modes of transportation also has an important role in transportation process especially interaction between a region to another region. Marler in [43] mentioned that the interaction between two different places in the use of its place then one must decide in what way to connect the two areas. If you can use a telephone and correspondence, there is no need for a trip, but if someone needs a physical presence in the area, there is a selection of modes of transportation to be used by the person, whether walking or using a vehicle.

Transportation network is also an element forming a residence environment for humans in doing activities. Theory of Ekistics proposed by Doxiadis in [46], stated that beside transportation, that environment is formed by the nature, man, society, shell (home / residence), and the last is the network including transport network. Systematically, these five ekistic elements form an environment in which humans live. Nature is a place for human as an individual to live in it and form a community. The formation of humans in nature constitutes a social group known as society, which of course needs a shelter for them to live. Shells are growing, becoming larger and more complex, and requiring a network. Based on that, in principle, a human resident consists of content and place, both human as an individual and as a society. Winarno in [47] describes the elements of ekistics as a physical expression of a community that is organically related to each other.

\section{CONCLUSION}

Based on the description in findings and discussion in the previous chapter, it can be concluded that with the increasing competition in the international tourism market would emerge new tourist destinations, and affect the existing tourist destinations, so that the existing tourist destinations must protect and strengthen their competitive advantage and this is also a challenge for every tourist destination. Therefore, in order to be competitive, tourist destinations offered to tourists should provide a superior experience compared to other tourist destinations. In this way only, the tourist destination will be chosen by potential tourists as a place to be visited. This can be achieved if we plan it well before. In order to attract the attention of potential tourists and tourist decisions (destination advantages over other destinations), the right choice, development and implementation of successful strategies for specific competitiveness become very important. As a result of the successful implementation and achievement of the main goal (increasing the visit of tourists), tourist destination will get significant income from tourism, which its positive effects will be felt in the entire tourist destination directly or indirectly related to tourism. Thus, it will lead to faster and greater economic development in tourist destination and higher quality of life for the residents.

Furthermore, tourism stakeholders need to notice that tourism has been able to develop and offer leisure activities, awareness of the importance of culture and the exchange of goods / international economy and provide employment and income in coastal cities. Other studies have also largely justified the economic impact of tourism in a region that is generally understood at two different levels: national and local levels. At the national 
level, the impacts of tourism, especially those that meet foreign tourists, can significantly affect their ability to get income in form foreign exchange, therefore contributing positively to the country's balance of payments. At the local level, job creation or unemployment reduction has been identified as one of the most prominent benefits in tourism development. With these economic benefits, then automatically the standard of living that citizens will also increase. In order to focus on the advantage of competetive destinations, a macro business perspective is needed for the entire tourism industry, which means that all stakeholders should work together by focusing on the general benefits of the destination rather than individual interests. Social media such as Flickr, YouTube, Instagram, facebook, twiter also become very effective strategies in developing and maintaining the level of competition for tourist destination.

This research is very simple because it only uses literature study approach so that it is affected by the author's assumption and not based on real and specific phenomenon that exist in certain tourist destination. Further research needs to be done by adding objects and instruments and also clear subjects to be used or to be studied, so that the results of the research would be clear and objective, and its usefulness will also be clearer. For Sanur stakeholders, there are some things that need our attention, in order to strengthen the Sanur tourist area to become a sustainable tourist destination. Steps that need to be taken are 1) Improve transportation accessibility to Sanur tourist destination area. 2) Improve publications and promotion for Sanur tourist destination both domestically and internationally, 3) Shorten and simplify long process of bureaucracy for investment to be made at Sanur tourist destination to support tourism in Sanur tourist destination, 4) Provide education and training for local communities to enable them to participate in tourism at Sanur tourist destination professionally. 5) Improve the stability of security and peace of the Sanur tourist destination. 6) Divide the area into the zones based on the tourism activities on that zone. 7) Establish monitoring posts in areaa that prone to disaster to accelerate the spread of disaster information.

\section{REFERENCES}

[1] Indonesian Statistical Bureau, Bali Province. 2016.

[2] Culture and Tourism Office, Regional Bali, 2015.

[3] Nusantini, Ni Luh Ayu. "Atribut Destinasi Yang Mempengaruhi Loyalitas Wisatawan Berkunjung Ke Kawasan Sanur." Jurnal Master Pariwisata (JUMPA) (2016).

[4] Hendrayana, Made. "Strategi Pengembangan Makanan Tradisional Bali Pada Hotel Di Kawasan Sanur." Universitas Udaya Denpasar (2011).

[5] Budiasa, I. Wayan, et al. "The role of the Subak system and tourism on land use changes within the Saba watershed, Northern Bali, Indonesia." J ISSAAS 21.2 (2015): 31-47.

[6] Ritchie, JR Brent, and Geoffrey Ian Crouch. The competitive destination: A sustainable tourism perspective. Cabi, 2003.

[7] Evans, N., Stonehouse, G., and Campbell, D. Strategic management for travel and tourism. Taylor \& Francis, 2012.

[8] Poon, A. Tourism, technology and competitive strategies. CAB international, 1993.

[9] d'Hauteserre, A-M. "Lessons in managed destination competitiveness: the case of Foxwoods Casino Resort." Tourism Management 21.1 (2000): 23-32.

[10] Dwyer, L., and Kim, C. "Destination competitiveness: determinants and indicators." Current issues in tourism 6.5 (2003): 369-414.

[11] Enright, M.J., and Newton, J. "Tourism destination competitiveness: a quantitative approach." Tourism management25.6 (2004): 777-788.

[12] Cracolici, M.F., and Nijkamp, P. "The attractiveness and competitiveness of tourist destinations: A study of Southern Italian regions." Tourism management 30.3 (2009): 336-344.

[13] Gomezelj, D.O., and Mihalič, T. "Destination competitiveness-Applying different models, the case of Slovenia." Tourism management 29.2 (2008): 294-307.

[14] Koh, K.Y., and Hatten, T.S. "The tourism entrepreneur: The overlooked player in tourism development studies." International Journal of Hospitality \& Tourism Administration 3.1 (2002): 21-48.

[15] Golembski, G., and Olszewski, M. "The Spas of Salt Mine Bochnia ea Polish case." Innovation and entrepreneurship. Strategies and processes for success in tourism (2010): 135-149.

[16] Wang, Y., and Krakover, S. "Destination marketing: competition, cooperation or coopetition?" International Journal of Contemporary Hospitality Management 20.2 (2008): 126-141. 
[17] Pernecky, T., and Jamal, T. "(Hermeneutic) phenomenology in tourism studies." Annals of Tourism Research37.4 (2010): 1055-1075.

[18] Riley, R.W., and Love, L.L. "The state of qualitative tourism research." Annals of tourism research 27.1 (2000): 164-187.

[19] Deci, E.L., and Ryan, R.M. "Intrinsic motivation." The corsini encyclopedia of psychology (2010): 1-2.

[20] Goodson, L., and Phillimore, J. "The inquiry paradigm in qualitative tourism research." Qualitative research in tourism. Routledge, 2004. 48-63.

[21] Denzin, N.K., and Yvonna S. Lincoln. "Introduction: The discipline and practice of qualitative research." (2008).

[22] Dwyer, L, et al. "Attributes of destination competitiveness: A factor analysis." Tourism analysis 9.1-2 (2004): 91-101.

[23] Hidayat, A. Implementasi Kebijakan Pariwisata Dalam Perspektif General Agreement on Trade in Services (GATS) Suatu Studi di Kota Bandung. Disertasi. Program Pascasarjana Universitas Padjadjaran. Bandung. (2003).

[24] Hermana. Pengaruh Perencanaan stratejik kepariwisataan sebagai salah satu determinan manajemen publik terhadap pengembangan kepariwisataan Provinsi Banten. Disertasi. Program Pascasarjana Universitas Padjadjaran. Bandung. (2006).

[25] Wiyadi, I. Strategi Public Relations Dalam Membentuk Persepsi, Sikap dan Preferensi Wisatawan Mancanegara Serta Pengaruhnya Terhadap Pemosisian Industri Pariwisata Nasional. Disertasi. Program Pascasarjana Universitas Padjadjaran. Bandung. (2006)

[26] Suryahadi, Y. Analisis Persepsi dan Preferensi Konsumen Terhadap Kawasan Taman Nasional Kepulauan Seribu. Disertasi. Program Pascasarjana Institut Pertanian Bogor. Jawa Barat. (2009).

[27] Lopes, S.D.F. "Destination image: Origins, developments and implications." PASOS. Revista de Turismo y Patrimonio Cultural 9.2 (2011): 305-315.

[28] Mehmetoglu, M. "Typologising nature-based tourists by activity-Theoretical and practical implications." Tourism management 28.3 (2007): 651-660.

[29] Jaini, N., Anuar, A.N.A, and Daim, M.S. "The practice of sustainable tourism in ecotourism sites among ecotourism providers." Asian Social Science 8.4 (2012): 175.

[30] Soeroso, A. Pengembangan Pariwisata Hijau Di Wilayah Kaliurang-Kaliadem. https://library.binus.ac.id. (2008)

[31] Arida, N.K. Meretas Jalan Ekowisata Bali Dan Kabupaten Paser Provinsi Kalimantan Timur”, Disertasi. Program Pascasarjana IPB, Bogor. (2009)

[32] Pike, S., and Page, S.J. "Destination Marketing Organizations and destination marketing: A narrative analysis of the literature." Tourism management 41 (2014): 202-227.

[33] Robinson, Peter. Tourism: The key concepts. Routledge, 2012.

[34] Warpani, S.P., and Warpani, I.P. Pariwisata dalam tata ruang wilayah. Penerbit ITB, 2007.

[35] Yoeti, O. "A. 1996." Pengantar Ilmu Pariwisata.

[36] Larsen, S. "Aspects of a psychology of the tourist experience." Scandinavian Journal of Hospitality and Tourism7.1 (2007): 7-18.

[37] Bieger, T., and Laesser, C. "Information sources for travel decisions: Toward a source process model." Journal of Travel Research 42.4 (2004): 357-371.

[38] Gursoy, D., and McCleary, K.W. "An Integrative Model of Tourists'information Search Behavior." Annals of tourism research 31.2 (2004): 353-373.

[39] Xiang, Z., and Gretzel, U. "Role of social media in online travel information search." Tourism management 31.2 (2010): 179-188.

[40] Leung, D, et al. "Social media in tourism and hospitality: A literature review." Journal of travel \& tourism marketing 30.1-2 (2013): 3-22.

[41] Munar, A.M., and Jacobsen, J.K.S. "Trust and involvement in tourism social media and web-based travel information sources." Scandinavian Journal of Hospitality and Tourism 13.1 (2013): 1-19.

[42] Zehrer, A., Crotts, J.C., and Magnini, V.P. "The perceived usefulness of blog postings: An extension of the expectancy-disconfirmation paradigm." Tourism management32.1 (2011): 106-113.

[43] Peter, M., and Sherman, V. "Innate differences in singing behaviour of sparrows reared in isolation from adult conspecific song." Animal Behaviour 33.1 (1985): 57-71.

[44] Ariwangsa. 2012. Mountain Bike Park di Area Hutan Bedugul - Baturiti: Sebuah Potensi yang Bagus dari Pariwisata Olahraga dan Petualangan?' Tesis. Program Pascasarjana Universitas Udayana. Bali.

[45] Broadaway (2012). Bicycle Tourism And Rural Community Development: An Asset Based Approach' Journal Of Sustainable Tourism Vol. 8, No. 5.

[46] Doxiadis, C. A. "Water and environment." International Conference on Water for Peace, Washington, DC. 1967.

[47] Winarno, W.W. "Sistem Informasi Akuntansi." Edisi ke-dua, Penerbit UPP STIM YKPN, Yogyakarta (2006). 
International Journal of Advanced Science and Technology Vol.130 (2019) 